\title{
ILLUSORY-QUADRATURE PAINTING IN THE CHURCH OF ST. NICHOLAS, BISCOPE OF MIRA, IN KAMIANETS-PODILSKYI
}

\section{ІЛЮЗОРНО-КВАДРАТУРНИЙ ЖИВОПИС У КОСТЕЛІ СВ. МИКОЛАЯ ЄПИСКОПА МІРИ У КАМ'ЯНЦІ-ПОДІЛЬСЬКОМУ}

Стаття присвячена мистеитвознавчому розглядумаловідомого розпису каплички св. Домініка у домініканському костелі св. Миколая, єпископа Міри в Кам'янці-Подільському. Досліджується час постання, стилістичні й художньо-композиційні характеристики малярства.

Ключові слова: мистецтвознавство, живопис, домініканський костел св. Миколая, фрески.

Szczególny nastrój panował w kościele podominikańskim św. Mikołaja bpa Miry w Kamieńcu Podolskim podczas wieczornych nabożeństw. Słońce wysyłało pożegnalne promieni przez niewielkie okno, umieszczone nad chórem muzycznym. W pogodne dni odblaski słonecznych promieni wypełniały wnętrze, dosięgając najbardziej tajemniczych zakamarków świątyni. Odzwierciedlane były one w złoceniach ram, żyrandolach, lichtarzach, sztukateriach, które zdobiły sklepienia i ściany głównej nawy oraz portale kaplic. Wnętrze niejako przystrajało się delikatną złotą mgłą, utkaną z promieni zachodzącego słońca. Ten wspaniały efekt przyciągał uwagę licznych pielgrzymów i wiernych, którzy niejednokrotnie z różnych krańców miasta a nawet z Podola, ściągały do kościoła.

Efekt ów nie trwał długo - około godziny. Wraz z zachodem słońca złotomiodowa aura znikała.

Pierwsze wzmianki o dominikanach (fratres praedicatores - braciach kaznodziejach) na tych terenach i w Kamieńcu pochodzą z różnych źródeł. Najbardziej jednak wyczerpująco pisze na ten temat historyk zakonu Szymon Okolski w dziele "Russia Florida”. Ojciec Szymon wspomna, że siedziba powstała jeszcze przed 1370 rokiem, za książęcych czasów braci Koriatowiczów [4, s. 102]. Zachowane źródła archiwalne mówią, że już około roku 1370 istniał w Kamieńcu kościół zakonu.

W 1420 roku pożar miasta uszkodził zabudowania dominikańskie. Wkrótce jednak świątynia i klasztor zostały odnowione. Pseudobazylikowy układ świątyni oraz cechy architektoniczne (dojrzały i późny gotyk, renesans i manieryzm, baroko i rokoko) wskazują na wspólne rysy podobnych obiektów na północy Niemiec, w Czechach i w Polsce.

Około roku 1596 beneficjentami dominikanów kamienieckich stali się przedstawiciele rodziny Potockich, którzy wznieśli murowany klasztor, a do prawej nawy bocznej (od południa) dobudowali kaplicę kopułową Matki Bożej Różańcowej. W 1611 roku z funduszy Wojciecha Humieckiego, kasztelana kamienieckiego, powstaje druga kaplica kopułowa, dobudowana do północnej nawy, o cechach manierystycznych, poświęcona Najświętszemu Zbawicielowi.

Trzecią kaplicę - na cześć św. Dominika - zbudował Paweł Damiecki (herbu Prus) w 1628 r. [6, s. 164], który ofiarował środki na dobudowanie kaplicy ku czci św. Dominika, o czym świadczy tablica, znajdująca się dziś w katedrze kamienieckiej.

Kościół przyozdabiała jeszcze jedna kaplica, znajdująca się pomiędzy prezbiterium a kaplicą św. Dominika w której umieszczone były święte relikwie. Między innymi przechowywano tam cząstkę Krzyża Świętego oraz szczątki świętych Pańskich: św.św. Modesty, Felicysimy, Justyny, Kolumbana, Dezyderiusza, Klary, Tomasza z Akwinu, Iluminata, Jacka, Walentego etc.

Przez ostatnie ćwierćwiecze XVII stulecia Kamieniec przebywał pod panowaniem tureckim. Wszystkie chrześcijańskie świątynie miasta, w tym omawiany przez nas kościól, nowi gospodarze zamienili w meczety.

(c) Natalia Ursu, 2018 
Wiek XVIII staje się "złotym wiekiem” kamienieckiego budownictwa a kościół przechodzi kolejne renowacje. Najbardziej jednak znacząca, podjęta była w 1737 r. przez Michała Franciszka Potockiego. Nowy kolator aż 17 lat gruntownie odnawiał, przyozdabiał i wyposażał kościół i przyległy klasztor [8, s. 35]. Barącz podaje, iś tylko na wzniesienie klasztoru, oprócz materiałów, Potocki wydał 14000 zł polskich oraz organy, na które wydał 5000 zł. W celu zakupu książek do biblioteki klasztornej, jeździł do Rzymu [1].

W roku 1743 Papież Benedykt XIV podarował Michałowi F. Potockiemu relikwiarz ze szczątkami św. Aleksandra Męczenika. Donator zapraszał wówczas znaczących przedstawicieli w dziedzinie architektury i sztuki.

Prace renowacyjne prowadzone były pod kierownictwem znakomitego architekta Jana de Witte [7, s. 265], ówczesnego komendanta twierdzy kamienieckiej, którego młodszy brat Antoni wstąil do zakonu kaznodziejskiego w Kamieńcu Podolskim [3, s. 24]. De Witte jest autorem przebudowy i dobudowy wieży kościelnej, piętra klasztornego, etc. Po lewej stronie od wejścia głównego wznośi tak zwany "domek kolatorski”, w którym ostatnie lata swego życia mieszkał kolator (M. Potocki) za nim w roku 1757, 20 marca spoczął pod kaplicą św. Dominika [5, s. 37].

Michał Franciszek opiekuje się także renowacją przestrzeni wnętrza świątyni oraz wszystkimi szczegułami. Na poźiomie wysokim profesionalistycznym, w jedynym stylu rokoka ozdabia sztukateriami nawę główną i boczne, dodaje do gotyckiego wnętrza kanelurowane pilastry, oraz nieco odbiegające od reszty, ale także rokokowe freski w kaplicy św. Dominika.

Wymieniona kaplica (7 x 5,5 arszyn (аршинъ) [8, s. 18]; 6,75 x 5,5 m) w kształcie wydłużonego prostokąta o sklepieniu kolebkowym (wysokości 8,45 m) w wieku XVIII została pryozdobiona malarstwem iluzorystycznym, wykonanym w technice "al fresco", przypuszczalnie przez znanego malarza br. Józefa Prachtla, trynitarza, pracującego na Podolu w świątyniach trynitarskich: w Kamieńcu, w Brahiłowie oraz przy niektórych kościołach dominikańskich (jak Szarawka - 80 km na północ od Kamieńca), etc. Wileński historyk sztuki Jerzy Hoppen wspomina o jedynym żródle, książce, modlitewniku ks. Krzyszkowskiego, wydanej w Wilnie r. 1843, która podaje opis prac trynitarza Józefa od św. Teresy o nazwisku Prechtl (Prachtl, Prestl), który urodził się 13 lutego 1737 roku we Wiedniu, gdzie także zdobył nawyki malarstwa ściennego. W roku $1758 \mathrm{w}$ Beresteczku wstąpił do zakonu Trynitarzy [2, s. 151-152]; zmarł w Brachiłowie w roku 1799. "Nie tylko obrazy, a te w wielkiej do podziwienia liczbie, ale też i całe kościoły sam własnoręcznie al fresko malował, miłośników sztuk pięknych talentem swoim zachwycał, a razem i zadziwiał swoją odwagą na wysokich pod same sklepienie rusztowaniach, i wytrwałością w tak trudnej, nudzącej i ciężkiej, najbardziej w optycznem malowaniu podniebień wielkich kościołów pracy; a którą częstokroć, leżąc tylko na wznak, albo w innych przykrych położeniach ciała, odbywać musiał" [2, s. 152].

Pobyt J. Prechtla pod czas prowadzenia renowacyjnych prac w klasztorze trynitarskim w Kamieńcu, który mieścił się dośc blisko od zespołu Dominikańskiego, bowiem przy Rynku Ormiańskim, w odległości kilku domów, nie mogło nie przywruczić uwagę OO Dominikanów kamienieckich. Wówczas w najblizszym otoczeniu dominikanów nie dostrzegamy takiej klasy malarzy, Józef od św. Teresy - jedyny uchwytny malarz trynitarski II połowy XVIII w. na kresach południowo-wschodnich. Możemy przypuśczić, że malowidła w kościele św. Mikołaja (prawdopodobnie juz po smierci (1757 r.) fundatora ostatniego remontu F.M. Potockiego) były wykonani wcześniejsze aniżeli u Dominikanów w Szarówce.

Freski w kościele Dominikanów w kościele Przenajświętszej Marii Panny w Szarówce oglądał Król Stanisław August Poniatowski 1781 roku, powracając z Kamieńca Podolskiego [11, s. 245-246]. Do Szarówki trynitarskiego artysta zaprośil Ignacy Dulski (1773 r. ?) Styl malowideł Prechtla wyróżniał się oryginalną kolorystyką, która przewidywała osiągnięcie efektów splendoru dzięki harmonii, włączenia złota, kolorystycznych walorów malowidła "al fresko" na kształt kobiercowej faktury, imitacji wyszukanego zielonego marmuru i małachitu. Podobne podejście spostrzegamy przy autentycznych marmuryzowanych portatelach oraz męsach ołtarzy, ambonie i innych komponentach wyposażenia wnętrz, tworzących fakture drogiego kamienia, mającego szmaragdowy 
koloryt powierzchni [9, s. 2826-284]. Świadome łączenie zielonego ze złotem miało transcendentną implikację: triumf życia, nadzieja na zmartwychwstanie, duchowe wtajemniczenie. Podobno do śriedniowiecznych tłumaczeń Raj miał metaforyczne przedstawienie w kolorystycznym akordzie złotych, zielonych i różowych tonów.

Podobna metaforyczno-enigmatyczna idea brzmiała w aranżowanej iluzorystycznie kaplicy św. Dominika świątyni Kamienieckiej, gdzie głównym akcentem było malowidło z naciskiem na połączenie (porównianie) złota i sztucznie stworzonej teksturze szmaragdowo-malachitowych kolumn.

Iluzorystycznie malowana na ścianach i sklepienni historia zawiera obraz-opowieść o życiu mnichów dominikanów, cudownym uwolnieniu $\mathrm{z}$ więzienia jednego z przedstawicieli Rodziny Potockich z tureckiej niewoli, dokonanym przez założyciela zakonu - św. Dominika, obraz którego jest namalowany na sklepieniu kaplicy. Patron kaplicy przedstawiony w glorji, w niebie, na chmurach, w otoczeniu aniołów, pomogających podtrzymywać chrześcijańskie symbole wiary (krzyż, girlandy kwiatów, etc). Iluzorystyczne "al fresko" dozwoliło utworzyć we wnętrzu nowe efekty przestrzenne i perspektywne. Kompozycja pełna pafosu, rokokowej kolorystycznej dzielikatności, uczucia światła i radości, którzy objawiają się w pełnych życiowej radości obrazach świętych dominikańskich, w skomplikowanej, arczitektonicznie obramiającej główną historię dekoracji. Cały zespół freskowy podobny do wyniosłych działań teatralnych. Tworzenie malowanych obrazów ściennych w stylu iluzionistychnym na Ukrainie połowy XVIII wieku przypada na okres anałogicznego malarstwa w wówczesnej Europie, gdzie jego rozpowszechnienie sięga swoistego apogeum.

Malowidło sklepienia kaplicy ukazuję Apoteozę św. Dominika, otoczonego aniołami i dominikańskimi świętymi. Grupa świętych dominikańskich, przedstawiona mniszkami, stojącymi na balkonie, otoczonym balustradą, zwraca swoje spojrzenie do św. Dominika z prośbami modlitewnymi, o jego pomoc, wstawiennictwo, błogosławieństwo i opiekę dla Zakonu. Treść opowieści malarskiej tzw "Dysputę Świętych", która jeszcze nie do końca wyjaśniona przez naukowców, wykazuje konkretne wydarzenie i wymaga dalszych badań. Malowidła są wykonane w stylu rokoko z tą samą wirtuozerią jako desiudeporty (overdoor) wejść do innych kaplic kościoła.

Pełny profesionalizm malarza, doskonała znajomość perspektywy, efekty światłocienia obejmują i łączą wszystkie elementy architektoniczne w iluzorycznym stylu: arki, łukowate wejścia otworów balustrady, wazony z bukietami kwiatów, otwór laterny, w którym można oglądać przestrzeń nieba.

Malowane console podtrzymuja iluzjonistycznie zdobiona rame okna. Każdy składnik (element) freski i malowidła w ogóle ma zewnętrzność przestrzeni i głęboki wypukłości obrazu. Każdy składnik freski i malowidła w ogóle pełna głębokiego realizmu, przestrzeni i efektów objętości. Malowidla połowy XVIII stulecia (rokoko) na ścianach, od podłogi do sklepenia kolebkowego, zajmowały bl. $60 \mathrm{~m}^{2}$. Freski mieściły na ścianach malowane rozkrepowani w stylu barokowym gzymsy, w oparciu o kapitelach kolumn w porzadku kompozytnym. Podwójne kolumny flankują malowany na ścianie cyborium (tsyboriy), na tle którego w centrum ołtarza, w ramie (tumbie) drewnianej, znajdował się główny obraz kaplicy - św. Dominik pełnej długości, malowany w oleju na płótnie. Drewniany ołtarz otoczony iluzjinistycno malowanym portykiem i flankowany czterema kolumnami o fakturze malachitowej ze złoconymi kapitelami i tympanonem, był pomalowany w kolorach granatu i zieleni. Powyższe umieszczony obraz Papieża, św. Gregorza, otoczony przez 2 duże i 9 mniejszych aniołów. Obraz św. Dominika ozdobiony srebrnym pozłacanym dekorom: promienie wokół głowy, gwiazda na czole, klamrą na pasie, prętem z 3 części w jednej ręce i książką, z pozłacanym okładem w drugiej. Na zasłonie był obraz św. Franciszka, na ranach (stygmatach) którego zlokalizowane 5 gwiazdek srebrnych złoconych [10, s. 5]. Obraz zdobiony złoconymi promieni srebrnymi i koroną [10, s. 11].

Arka, archiwolt i pilastry, flankujące wejście do kaplicy klasycznie powściągliwy, dobrze zdefiniowane. Nad łukiem - w technice płaskorzeźby umieszczono rokajl w kstałcie kartusza, zestawiony z komponentów heroizowanych (włócznie, flagi, itp), połączonych rokokowym dekorem. Artystyczny wystrój kaplicy św. Dominika wyróżnia ją od nawy głównej i dwóch kaplic renesansowych. Malowanie iluzoryczne kaplicy zrealizowane profesjonalnie, na poziomie, charakterysnycznym dla pęzla mistrzowskiej klasy. Jednakowe techniki, elementy formacyjne, proporcjonalne relacje, teatralne iluzoryczne 
podanie, manera wykonania, faktura i charakterystyczny szmaragdowo-zielony ze złotem koloryt wskazują na podobieństwo "al fresko" w kaplicy św. Dominika kościołu Dominikanów do fresków kościoła Przenajświętszej Marii Panny w Sharówce, gdzie podtwierdzono, że malowanie dekoracji, wykonanał trynitarsky mnich Jósef od św. Teresy [11, 245-246]. Niestety, freski XVIII wieku pęzla Prehtlya później było poddane niekwalifikowanej restauracji.

W przestrzeni sakralnej podominikańskiego kościoła św. Mikołaja dostrzec można symbolikę głębokiej wiary, połączoną z teatralnością, właściwą dla stylów baroko i rokoko, akcentującą kruchość i przemijanie świata oraz nieskończoność i wspaniałość jego Stwórcy.

Od roku 1997 kościołem, skazanym wcześniej na unicestwienie na skutek pożaru 1993 r., opiekują się ojcowie zakonu św. Pawła Pierwszego Pustelnika - Paulini.

\section{Spis literatury}

1. Barącz S. Rys dziejów zakonu Kaznodziejskiego w Polsce, II t., Lwów, 1861, 432 p.

2. Hoppen J. Malarz Jan Prechtl - brat Józef od Św. Teresy [in:] Prace i Materiały Sprawozdawcze Sekcji Historii Sztuki i nauk w Wilnie, Wilno, 1938/39, T. III.

3. Hornung Z. Jan de Witte architect kościoła Dominikanów we Lwowie, Warszawa, 1995.

4. Okolski S. Russia Florida Rosis et Liliis, Leopoli, 1646.

5. Prusiewicz A. Kamieniec-Podolski. Szkic historyczny, Wilno, 1915.

6. Setsynskyi E. Horod Kamenets-Podol'skii. Ystorycheskoe opysanye, Kyev, “Typ. S.V. Kul'zhenko", 1895.

7. Spież I. A. OP. Dominikanie w Kamieńcu Podolskim [in:] Pasterz i twierdza, Kraków Kamieniec Podolski, 2001.

8. Wizyta w Podolsko-Kamienieckiey Dyecezyi Kościoła Zakonnego WW OO. Dominikanów Kamienieckich, Kam'ianets'-Podil's'kyi derzhavnyi mis'kyi arkhiv (dali - KPDMA), F. 685, Ryms’ko-katolyts'ka dukhovna konsystoriia, Op. 2, sprava № 58, 1850.

9. Wizyta w Podolsko-Kamienieckiey Dyecezyi Kościoła Zakonnego WW OO. Dominikanów Kamienieckich, KPDMA, F. 685, Ryms'ko-katolyts'ka dukhovna konsystoriia, Op. 4, sprava № 21, 1823.

10. Wizyta w Podolsko-Kamienieckiey Dyecezyi Kościoła Zakonnego WW OO. Dominikanów Kamienieckich, KPDMA, F. 685, Ryms'ko-katolyts'ka dukhovna konsystoriia, Op. 4, sprava № 23, 1824.

11. Wołyniak (M. J. Giżycki). Wykaz klasztorów dominikańskich prowincji ruskiej, Kraków, 1923, Cz. 2.

The article examines the little-known paintings of the chapel of St. Dominic in the Dominican church of St. Nicholas, Bishop of Mira, in Kamianets-Podilskyi from the point of view of art criticism. The interior of the church, its characteristic artistic and compositional features are analysed. The history of building of the main castle of the church and four side chapels is briefly given. The role of beneficiary Franz Michat Potocki in the process of restoration of the church after the Turkish invasion is revealed. The head of the restoration work, architect Jan de Witte is mentioned. The paper emphasises on the third chapel devoted to the founder of St. Dominic's Order. The author studies the period of illusory-quadrature painting formation and its connection with Western European art. The assumption about probable authorship, stylistic and artistic-compositional characteristics of painting is proposed. The main dates of life and work of the author of frescoes, the Trinitarian monk Joseph of St.Teresa, are given. The author analyses the scenes depicted on the walls and vault chapels, shows the difference between this building and the decorated earlier chapels of the Rosary of Blessed Virgin Mary and Jesus Christ. The sacred metaphor and deep meaningful symbolism of thematic images are described.

Key words: art criticism, painting, Dominican church of St. Nicholas, frescoes. 